\title{
Whole Person Learning: Embedding Ethical Enterprise Leadership In Business Education
}

\author{
E. Vincent Carter, California State University, Bakersfield, USA
}

Mary Donohue, Dalhousie University, Canada

\begin{abstract}
This study introduces a collaborative business education curricular design known as "whole person learning." The post-financial crisis market environment requires business education to encompass curricular, commercial and community skills. Drawing on the Toronto based National Mentoring Program (NMP), "whole person learning" develops business leadership ethics competency within a personal experience context. Exposure to mentorship institutions imparts an awareness of macro societal patterns, while experience with mentorship interaction instills an aptitude for micro skill performance. Therefore, "whole person learning" enables business curricula to connect academic scholarship, application strategy, and aspiration service outcomes.
\end{abstract}

Keywords: Business Education; Ethical Enterprise; Mentorship; Pedagogy; Service Learning

\section{INTRODUCTION: THE CIRCUMFERENCE OF BUSINESS EDUCATION}

e $\mathrm{n}$ the post-financial crisis environment, business education curricula must embrace commercial and community stakeholders to train ethical enterprise leaders. Business scholars concur that strategic goals are compatible with societal gains (Rendtorff, 2009; Porter and Kramer, 2006). Ethical business leadership is neither an exclusive course nor concentration. It is conditioned by the inclusive configuration of learning delivery. Academic skill in the classroom should be validated with application strategies undertaken at companies and vested in aspiration services to uplift communities. This triangular alignment of the whole society leadership at a macro level (e.g., collegiate, commercial, community) can also model whole student learning dimensions at a micro level (e.g., academic, application, aspiration). "Whole person learning" aligns course pedagogy, commercial practices, and community participation using a collaborative curriculum design.

Canvassing the business education research, the need for a common thread to connect disparate streams of thought becomes apparent. Although competency-based curriculum planning is advanced (Chyung et al., 2006), research rarely addresses common learning competencies that unite separate research streams. Likewise, the goal of integrated business curricular designs (Goorha and Mohan, 2010; Athavale et al., 2008), do not explicitly incorporate multiple learning delivery modes or collaboration with external stakeholders. These myopic perspectives constrain the holistic nature of ethics skill learning and ethical society leadership.

\section{Carving Separate Angles of a Common Learning Competency}

The "whole person learning" paradigm reconstructs the organic business education cycle of skill, strategy, and service to cultivate ethical leadership competency. In contrast, the prevailing tendency among business education scholars is to deconstruct learning into curricular compartments (e.g., assessment, pedagogy, instruction, online platforms, internship, service learning, etc.). Most literature streams carve out separate angles, instead of encompassing the shared circumference of learning competency (see Figure 1). 


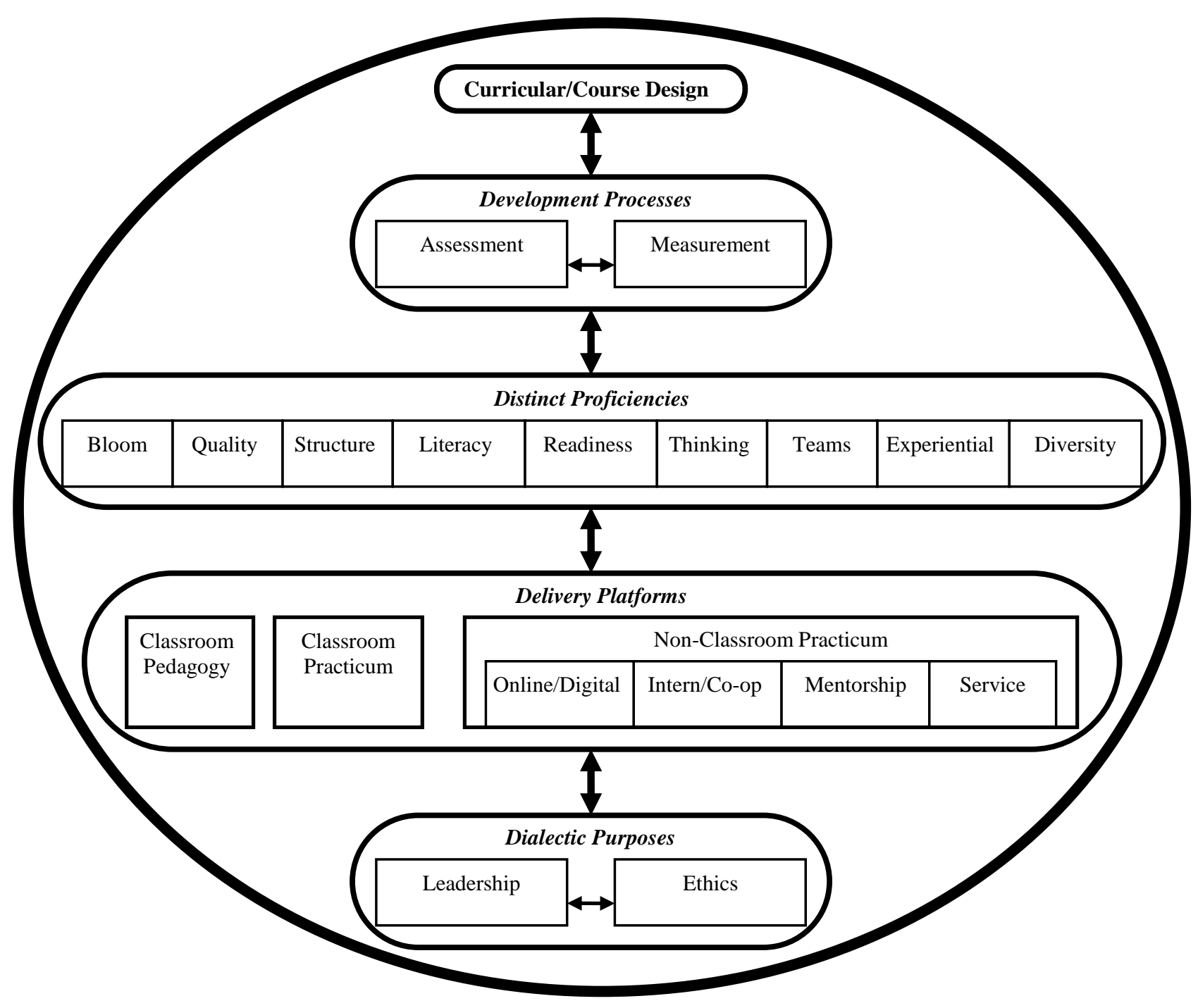

Figure 1: Business Education Compartments of a Circumferential Learning Competency

In terms of curricular/course development, learning assessment and assurance is a primary angle of business education research (Stivers and Phillips, 2009; Martell, 2007; Marshall, 2007). Learning measurement studies are closely associated with assessment (Weldy and Turnipseed, 2010; Gardiner, et al. 2010), including strategies for achieving the "continuous improvement" principles (Pritchard et al., 2010) and evaluation practices stipulated by the AACSB for business education curricula (Pringle and Michel, 2007; Miles et al., 2004).

As the literature shifts from curricular development to course design, learning proficiency is another prominent business education research angle. The proficiency of students at various skills is examined with themes such as Bloom's education taxonomy (White, 2007; Bloom, 1956), content quality (Beard, 2009; Peters et al., 2005; Denton et al., 2005), course structure (Dynan et al., 2009), subject literacy (Heinrichs and Lim, 2009), student readiness (Payne et al., 2008), critical thinking (Peach et al., 2007; Page and Mukherjee, 2007; Crittenden and Woodside, 2007), collaboration and teams (Winter et. al., 2008; Hansen, 2006; Yazici, 2005), experiential participation (McCarthy and McCarthy, 2006; Wingfield and Black, 2005), and cultural diversity (Mitry, 2008; Landry et al., 2004). 


\section{Fracturing Curricular Design Based On Learning Delivery Format}

With the emergence of alternative formats for learning delivery, business education scholars carved new research angles based on instructional modes. Pedagogy is assigned the role of addressing improvements in the traditional delivery of instruction, both on campus and online. Presently, the literature favors business course instruction that is participatory, experiential, and interactive (McCarthy and McCarthy, 2006; Munoz and Huser, 2008).

Most recently, online delivery platforms (Robinson and Hullinger, 2008) are typically studied as novel learning modes (Eastman et al., 2011; Miller et al., 2007; Quible, 2005), often with discipline specific applications (Lam, 2009; Peng, 2009; Smolira, 2008; Grzeda et al., 2008), instead of media for integrating business education holistically. Rather than explore the potential of digital media to synthesize business education skills, subjects, and stakeholders, attention is devoted toward evaluating faculty perceptions and student satisfaction with online and web-based instruction versus traditional pedagogy (Beqiri et al., 2009; Anakwe, 2008; Gibson et al., 2008; Smith and Mitry, 2008; Krentler and Willis-Flurry, 2005). However, the future possibilities of digital learning are reflected in attempts to integrate platforms across curricula (Cauley et al., 2009) and cross-cultural Internet sharing (Volkema and Rivers, 2008).

Practicum covers a wide range set of arrangements for "hands-on" skill-building. Properly defined, practicum encompasses every learning mode outside of traditional course pedagogy. That pertains to all learning delivery modes that add "real world" business methods to traditional course instruction. Classroom practicum activity includes client-based projects, where business professionals guide students, as well as case studies, scenariobased approaches, simulations, and field data research, or consulting based on direct market contact (Xu and Yang, 2010; Sciglimpaglia and Toole, 2009; Theroux, 2009; Callanan and Perri, 2006). Most notably, the rise in entrepreneurship courses and programs (Shinnar et al., 2009; Hazeldine and Miles, 2007; Levenburg et al., 2006) constitutes a curricular transition from traditional pedagogy to business education practicum. In this context, classroom practicum brings the "real world" to students (Hyman and Hu, 2005; Holowczak, 2005; Goel and Straight, 2005) whereas non-classroom practicum modes bring students to the "real world."

Internships are the most prevalent learning delivery mode for educating students in the "real world" business environment (Weible, 2009). In that regard, internships can impart an entire range of competencies in the business curricula (Dillon et al., 2011; Rothman, 2007). Co-op and work-study arrangements are learning delivery modes similar to internships.

Service learning fills the void of community engagement that is left by exclusively focusing business education on "real world" experiences with commercial enterprises. Initially scant ten years prior (McCarthy and Tucker, 1999), the prevalence of service learning has grown in business curricula with the recognition of corporate social responsibility (Cornelius et al., 2007), as well as the interdependence of commerce, civics, and community (Govekar and Rishi, 2007; Andrews, 2007).

Mentorship is a unique hybrid that fuses the "real world" experiences of internships and co-ops, the societal scope of service learning, and the tutelage of practicum clients (Hansford et al., 2002; Fullan, 2001a). As a result, business education delivered through mentorship can be configured to align societal stakeholders with scholastic skills (Donohue et al., 2010). Unfortunately, this holistic potential is hindered by treating mentorship as an isolated delivery mode for leveraging business and alumni connections (Plice and Reinig, 2009; Finney and Pyke, 2008).

Like music, learning is furthered by integrating, not isolating, elements. Just as the musical elements of tone, melody, rhythm, harmony, and lyric lose meaning in isolation, so too does business education become diluted when delivery platforms lack coherence. This holistic framing is similar to Gardner's $(1999,1983)$ concept of "multiple intelligence." Consequently, "whole person learning" unifies business education around the purpose of ethical leadership. 


\section{Ethical Leadership Competency and Whole Person Learning}

Leadership and ethics dominate the business education literature. Accordingly, the premise of "whole person learning" is widely validated and can serve as a foundation for developing curricula that cultivate ethical business leadership. More important, leadership and ethics naturally bridge the boundaries between curricular academics, commercial application, and community aspiration. This inclusive vision of business leadership is being referred to as "connected capitalism" (Bisoux, 2010). Leadership studies in the business education literature draw heavily on management exemplars (Martelli and Abels, 2010; Butler et al., 2008) and skills-based coaching (Butler et al., 2008), but recognize the transcendent nature of leadership skills (Markulis et al., 2006) that are learned from pedagogical education, private enterprise, and public engagement.

\section{Realizing Ethical Enterprise Principles and Practices}

Increasingly, the essential role of ethics in enterprise is coming to the forefront of business leadership. Business education accreditation standards regard ethics as a prerequisite for strategic aptitude as well as societal awareness (Phillips, 2004). However, aside from occasional forays into social responsibility (Nicholson and DeMoss, 2009) and social-entrepreneurship (Mars and Garrison, 2009; Schlee et al., 2009), business education research primarily emphasizes a strategic ethics aptitude. These studies of micro level ethics skills address learned behaviors (Gundersen et al., 2008; Wilson, 2008), personal values (Hemmingway, 2005), management perceptions (Nguyen et al., 2008), "value creation" (Weinstein and Barrett, 2007), and analytical techniques like the "balanced scorecard" (Beard, 2009).

Societal ethics awareness is the mantle of an emerging management philosophy known as "ethical enterprise," which fully captures the fundamental purpose of "whole person learning." Recently posited in an American Management Association report titled "The Ethical Enterprise" (AMA, 2006), the central premise is a transformation from closed to open systems for business knowledge flow. Conventional business education adheres to a closed system of knowledge flow wherein business functions comprise learning content and business faculty teach learning curricula. By contrast, "ethical enterprise" frames the flow of business knowledge as an open system encompassing societal stakeholders. So, for business education, "ethical enterprise" opens both the periphery of learning content and the providers of learning curricula instruction:

Business schools have a responsibility to provide practitioners with training in the basics of ethics which would ideally lead to an informed workplace and act as a catalyst to stimulate socially and ethically grounded corporate activities and programs. (Cornelius et al., 2007, p.118)

\section{Raising the Whole Person Learning Paradigm}

Frye (1963) suggests that education is more than just connecting with students' minds - it is about engaging the "whole person" or student. Although Frye's (1963) writings primarily address the subject of literature, it is clear that the "whole person" paradigm is pliable to business education as a pedagogical design (MacRae-Campbell, 1997, 1988), course content delivery method (Rogers and Freiberg, 1993) and "transformative learning theory" (Taylor, 2007). Therefore, "whole person learning" is woven from this parallel research to align the academic, application, and aspiration aptitudes of business education curricula (see Table 1).

Table 1: Whole Person Business Curricula Academic, Application, and Aspiration Aptitudes

\begin{tabular}{|l|l|l|}
\hline Academic Aptitude (Learning) & Application Aptitude (Leading) & Aspiration Aptitude (Living) \\
\hline Student-Orientation & Strategic-Orientation & Service-Orientation \\
\hline Education Skills & Execution Skills & Ethical Skills \\
\hline Course Principles & Company Practices & Community Purposes \\
\hline
\end{tabular}

\section{AN EXPLORATORY WHOLE PERSON LEARNING RESEARCH PROJECT}

This study examines mentorship as a vehicle for aligning commercial and community lessons with course learning outcomes. The proposed 'whole person learning' mentorship approach is pioneered by the National 
Mentoring Program (NMP) based in Toronto, Canada. Mentorship is well suited for the business education goal of combining experiential learning with ethical leadership to instill "whole person" competency. In particular, the NMP introduces "service learning" with community organizations as a third angle to complement the typical dyadic mentorship arrangement that pairs course students and company managers. Service learning is defined by the National and Community Service Act (1990) as:

... a method under which students or participants learn and develop through active participation in thoughtfully organized service that is conducted in and meets the needs of a community; ... and with the community; and helps foster civic responsibility; and that is integrated into and enhances the academic curriculum of the students, ... and provides structured time for the students or participants to reflect on the service experience. (NCSA, 1990, p. 5)

This triangular design is posited to improve business students' grasp of the macro societal and micro strategic balance between educational obligations, enterprise objectives and ethical outcomes. Echoing Pfeffer and Fong (2004), the proposed model links business education with its commercial and community stakeholders. This individual interaction within a triangle of collective collaboration comprises the NMP model of "whole personal learning' (See Figure 2).

Citing the AACSB Ethics Education Task Force (Phillips, 2004), these interpersonal mentorship experiences serve to strengthen students" "individual integrity" to "focus on the link between leadership and values."

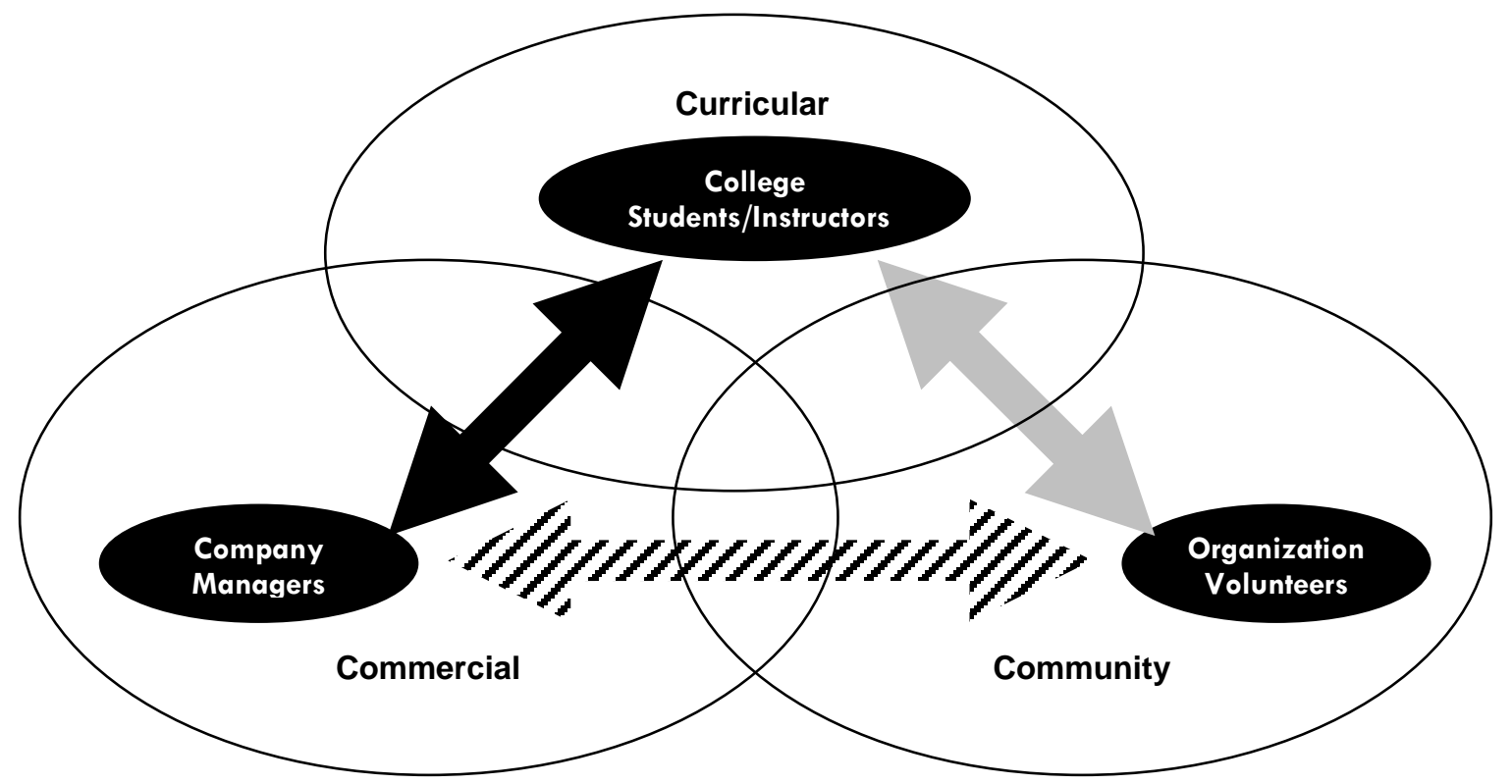

\begin{tabular}{|c|}
\hline Triangular Whole Person Learning Collaboration \\
\hline$=$ Experiential Learning Competency (Curricular/Commercial) \\
\hline
\end{tabular}

Figure 2: Triangular Whole Person Learning Paradigm 


\section{Research Description - The National Mentoring Program (NMP)}

This study documents recent National Mentoring Program (NMP) feedback. Exploratory case observations assess students' 'whole person' learning (course), leading (company), and living (community) experiences. The NMP is an eight month course module that enlists 19 students from four different Canadian universities as both company interns and community volunteers. Feedback was also obtained from company mentors at a major Canadian corporation, as well as non-profit organization community mentors within proximity of business operation sites.

\section{Research Findings - Modeling Ethical Leadership in Business Education Curricula}

The NMP study revealed insights regarding the ethical enterprise leadership competencies observed for business education students. These competencies are modeled using an integrative framework that captures their role in cultivating "whole person learning" as well as relationships with other competencies that emerged from case observations (See Figure 3).

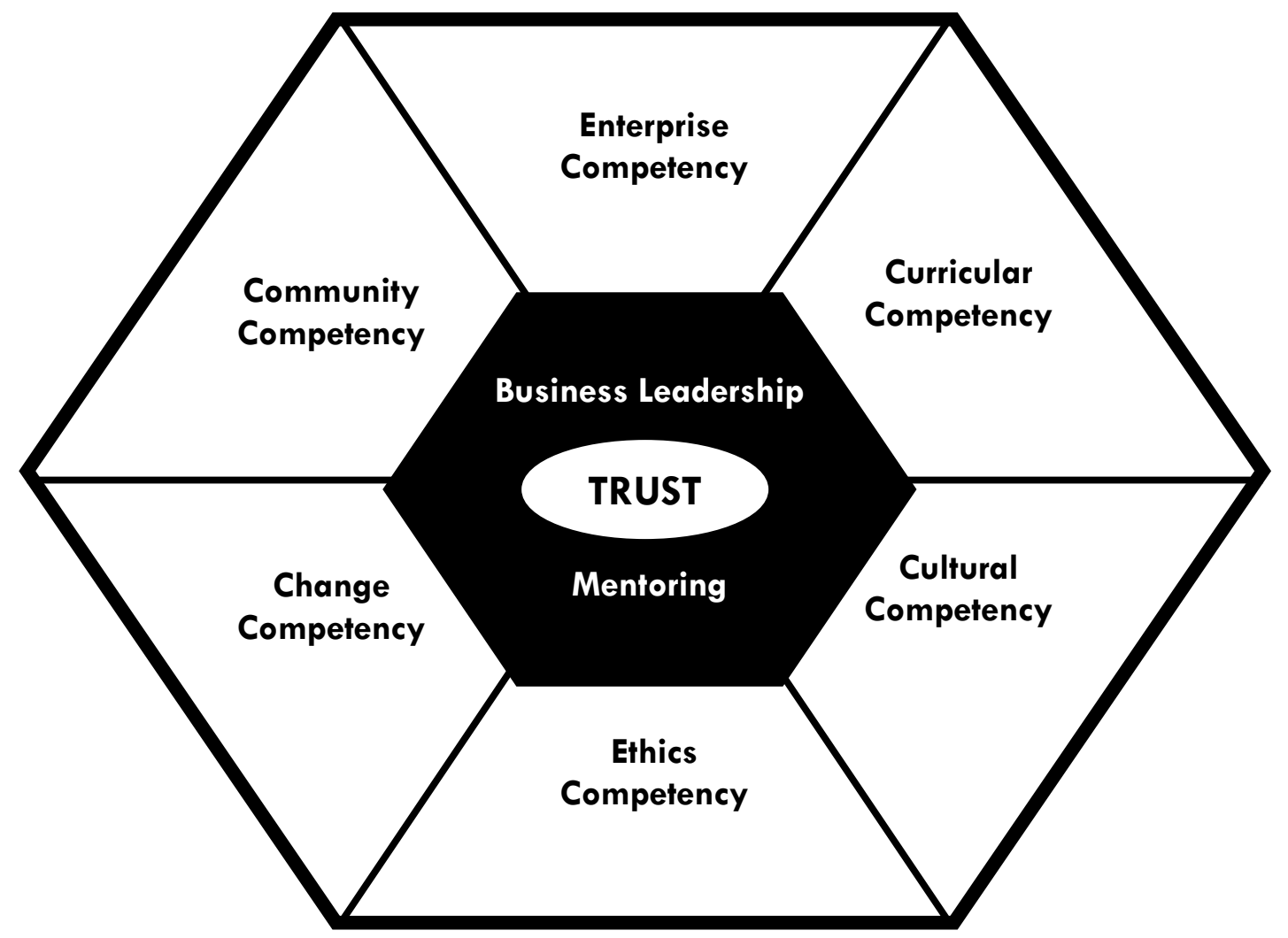

Figure 3: The Whole Person Model of Business Learning, Living and Leading Competencies

The integrative framework depicts the seven focal themes as a 'whole person' wheel of ethical business leadership competencies, rotating around the central theme of trust. The wheel of competency themes consists of community, enterprise, curricular, cultural, ethics, and change. The central axis of trust propels the revolving circle of ethical enterprise competency themes. Although the model represents an inclusive combination of both individual (micro) and collective (macro) NMP experiences, the design also juxtaposes key theme properties to guide 'whole person learning' goals.

Six circumference themes comprise a bottom set of three individual competencies and a top set of three collective competencies. Also, the model balances the primary individual and collective competence associated with 
each NMP 'whole person learning' partner. Community experiences are continuously renewed by encouraging people to embrace change. Enterprise experiences are kept responsible by embedding professional ethics and curricular experiences are inclusively created within the cultural spectrum of learning achievement. To preserve student anonymity, pseudonyms are used for the testimonies supporting "whole person learning' themes.

\section{Enterprise}

Enterprise competency appraises students' overall familiarity with commercial firms, as well as the specific job functions performed by mentor professions. Macro attributes of the enterprise competency expose students to the dynamics of global commerce within which mentoring companies compete. However, most feedback addresses micro level familiarity with professional work functions. Students understand that corporations must demonstrate leadership to attract smart young talent; they are also aware they are a valuable commodity to which corporations direct their marketing. It is their understanding of this that brought about the corporation's participation in the program. After participating in the program, Anderson grasped this dual role:

I think the company engaged with charities in a unique way that enabled them to make a difference beyond the simple act of writing a check. At the same time, I think the company wanted to establish a connection with the future of business and non-profit leaders coming out of the top business schools in Canada.

\section{Curricular}

The process of mentoring involved in the NMP enabled students to see the value in their professors' lectures. For example, Debra was able to see the practical aspect of one of her business courses through the mentoring program. She stated, 'Organizational behavior lessons became descriptions of my actual experience with managers, not just a lecture topic." Similarly, Dan appreciated understanding why his professors kept him to strict deadlines and meted out harsh evaluations. He stated, 'I have gained an appreciation for structure now and can see the importance of taking more action.' Like many of the other students involved in the program, Dan and Debra were able to see how their education is preparing them for employment. Being mentored by an executive corroborates what the professors say in class. Eileen felt that her "mentor was like my textbooks, except he was real and didn't quiz me."

\section{Cultural}

Cultural theme findings reflect students' collective alignment with a general cultural shift towards ethical enterprise in society at large, as well as multicultural competencies among individual students. In terms of the general cultural shift, corporate trust and shared community values are eclipsing monetary and material measures of business. This general cultural shift accurately portrays student mentorship experiences as they pursued the path of ethical enterprise marketing in courses, companies, and communities. Moreover, marketing educators have effectively leveraged these cultural shifts toward greater social-entrepreneurialism to design more meaningful courses (Mars and Garrison, 2009; Schlee et al., 2009).

In addition to universal cultural patterns, particular multicultural tendencies were observed in individual students. Preliminary NMP findings suggest that mentoring fosters confidence in students to construct unique cultural competencies, by fusing the best of their native cultural identity and the new situational identities gained through the NMP experiences. Mark stated that "prior to this experience, I believed I had potential and the right skill set but not necessarily the forum and support network to display them. I now have a lot more confidence to go out and try new challenges." Dan felt he needed more leadership experience outside of his familiar surroundings prior to his participation in the program. After completing the program, he remarked that the NMP experience expanded and diversified his perception of the types of people he can lead and the kinds of situations where learning occurs.

Madeleine was very realistic about her abilities prior to the program, but respect for her culture had, in the past, caused her to stifle her abilities. The National Mentoring Program enabled her to experiment in a new environment without cultural restrictions. 
The only difference was the environment in which I got to exercise my [leadership] skills. I now feel like there is a certain amount of maturity that has been developed through gaining more experience dealing with the outside world in a more professional manner, so I believe in my ability to exercise my skills on a broader scale, with different people, and with more flexibility and success.

For Dan and Madeleine, the mentoring period and the contact with their mentors enabled them to become more comfortable bringing forward new ideas and often helped reduce the stress they felt when pushing, what was for them, cultural boundaries.

\section{Ethics}

Ethics competency addresses the increased value of collective and individual principles of civic responsibility, economic equity, and ecological sustainability. In the NMP, ethics requires students to acquire an awareness of 'whole person learning' in order to achieve synergy among the curricular, commercial, and community dimensions in their personal lives. Several students expressed this internalization of holistic ethical principles and attributed this competency to NMP participation.

Students routinely reported conflicts between the objectives of company practices and the adverse implications of those outcomes for community organization principles. In the traditional business education classroom, these ethical dilemmas are commonly treated as problems with a "right answer", which students find by studying course material. However, for NMP students, the ethical dilemmas encountered were real and they actually have the power to bring conflicts to the attention of company managers engaged in less responsible practices. Typically, community organizations provided a range of alternatives for achieving the company objectives.

For example, a decision regarding the placement of outdoor advertising by the company had taken into account the potential negative consequences for community organizations serving youth. In another case, the insistence that students work overtime to complete company project assignments interfered with important community organization duties that had been jointly scheduled with company managers. Yet, in some instances, like targeting youth sports and entertainment venues for promotions, transparently conveying company intentions to community organizations was the only ethical benefit identified..

\section{Change}

Change competencies address the importance of adaptable learning and leadership strategies in a dynamic business education environment (Fullan, 2007, 2001a, 2001b). Mentoring affords students the opportunity to understand the change process because it involves relationship development. Jia, a new Canadian, was leery of change, but her mentor helped her through this process.

My mentor, John Smith, supported and encouraged me all the way through this program and his professionalism, positive attitude and good personality helped me go through a lot of difficulties. It's been eight months for my mentorship and he is almost my big brother right now. I really appreciate every little thing that John had shared with me - his experience, knowledge and creative thinking. I have been extremely lucky to be in this program and able to meet John.

By linking participant's professional and personal development needs, the NPM balances experiential learning enterprise skills with service-learning ethical skills.

\section{Community}

Community competency is founded on the goal of social well-being and integrates lessons from corporate social responsibility (CSR), social/societal marketing, and public policy. These emerging community competencies are observed in the NMP business students' enthusiasm toward community service and their familiarity with the benefits derived from connecting for-profit and non-profit organizations. The 'whole person learning' model 
recognizes that community experiences must be continuously renewed. Dan expresses this sense of renewed community competency in his assessment of the mentorship program.

I just thought of community as the place where people live and do not realize the range of life development activities that are provided by non-profit organizations to help people and even benefit companies.

Trust

Trust is the ethos of the NMP 'whole person learning' premise. Education scholars regard trust as a pivotal competency for society's leaders (Tschannen-Moran, 2004). As the central axis that coheres and coordinates mentorship experiences, trust is relied upon as "an organizing principle" (McEvily et al., 2003).

The NMP changed students' perception of and trust in the Canadian corporation's professional practices. Some students, such as Susan, felt that perhaps the company was participating in this program as a public relations or media exercise, but they didn't really care because they needed a summer job. Susan explained, 'prior to this program, I thought that they were primarily concerned with marketing their brand to increaseconsumption in society.' After participating in the program, Susan felt that the company achieved their objective of being a good corporate citizen and she no longer thought that it had just been a public relations or media content exercise. She came to the conclusion that they 'take CSR very seriously and has help fund many initiatives with non-profit organizations.'

Similar to Susan, Eileen had not formed an opinion of the Canadian corporation. She remarked that 'prior to the experience, I had limited exposure to the company and its philanthropic pursuits. Now I have a greater appreciation for the positive impact they have on the community.' These comments indicate that before participating in the NMP, like many students and consumers in general, Eileen and Susan did not trust the motives of corporations - they felt that corporate social responsibility was merely a marketing strategy. After direct interaction with actual managers and community members, students trusted the "ethical enterprise" motives of the corporation.

For example, Bonnie stated that "it was great to see that companies, value corporate social responsibility, not just by talk, but with actions.' Dan concurred, stating that they are 'making an effort towards being better corporate citizens and I can see first-hand how this is being achieved.' These results favorably reflect students' understanding of the Canadian corporation's efforts to build stakeholder trust into sustainable ethical enterprise leadership.

\section{WHOLE PERSON LEARNING LESSONS FOR BUSINESS EDUCATION CURRICULA}

Whole person learning is a collaborative business education curricular/course model designed to impart ethical leadership competency. In conventional curriculum design, pedagogy is ascribed as the academic duty of teaching know-how and practicum is assigned the application duty of show-how. Instead, the proposed "whole person learning" mentorship model provides business education instructors with a course design that aligns course pedagogy, company practices, and community principles.

Based on the nascent success of a three year NMP business education initiative, ethical business leadership competency has been improved by aligning student-oriented curricular learning with strategy-oriented commerce leadership and service-oriented community living. This triangular "whole person learning" model matches college students with both company and community mentors. Ethical business leadership competency is imparted through individual skill instruction and collective societal insight. Therefore, 'whole person learning' is advanced as a collaborative curricular design for developing ethical business leadership through "next generation education":

Just what does 'more' mean to $21^{\text {st }}$ century business education? For the business schools profiled here, it means designing degree programs that are more flexible, integrated, and experiential. It means exposing undergraduates to business practices earlier than ever; it means taking once-optional educational experiences - such as international study, consulting, and internships - and making them mandatory for every student; and it means 
emphasizing a wider range of skills than $20^{\text {th }}$ century business education ever addressed, including good judgment, personal awareness, and personal initiative. (Bisoux, 2009, p. 24)

\section{AUTHOR INFORMATION}

E. Vincent Carter, Ph.D. is an Associate Professor of Marketing at California State University, Bakersfield. Dr. Carter's business education research addresses curricular, pedagogical, and learning delivery topics. Dr. Carter's business education articles have appeared in several academic journals, including the Journal of Education for Business, Marketing Education Review, Journal for Advancement of Marketing Education, and the College Teaching Methods \& Styles Journal. E-mail: ecarter2@csub.edu (Corresponding author)

Mary Donohue, Ed. D. is the founder and president of the Donohue Mentoring System (DMS) based in Toronto Canada, and a regular business leadership and communication columnist for the Huffington Post and Financial Post business news publication of Canada. In addition to advising corporate clients on social marketing and philanthropy, Dr. Donohue has made regular presentations at academic marketing conferences in the United States and Canada. Dr. Donohue's research has been published in several national marketing and leadership conference proceedings, including the Marketing Educators' Association (MEA), the Marketing Management Association (MMA), and the Michigan Academy of Science, Arts and Letters. Presently, Dr. Donohue also serves as Adjunct Professor of Business at Dalhousie University, Canada. E-mail: $\underline{\text { maryd@ @btc.ca }}$

\section{REFERENCES}

1. Abraham, Steven Eric and Lanny A Karns (2009), "Do Business Schools Value the Competencies That Businesses Value?" Journal of Education for Business, 84 (6), 350-356.

2. American Management Association (2006), The Ethical Enterprise: Doing the Right Things in the Right Ways, Today and Tomorrow. New York: American Management Association / Human Resource Institute.

3. Anakwe, Bridget (2008), "Comparison of Student Performance in Paper-Based Versus Computer-Based Testing.” Journal of Education for Business, 84 (1), 13-17.

4. $\quad$ Andrews, Christine P. (2007), "Service Learning: Applications and Research in Business.” Journal of Education for Business, 83 (1), 19-26.

5. Athavale, Manoj, Rod Davis, and Mark Myring (2008), "The Integrated Business Curriculum: An Examination of Perceptions and Practices.” Journal of Education for Business, 83 (5), 295-301.

6. Beard, Deborah F. (2009), "Successful Applications of the Balanced Scorecard in Higher Education." Journal of Education for Business, 84 (5), 275-282.

7. Bequiri, Mirjeta S., Nancy M. Chase, and Atena Bishka (2009), "Online Course Delivery: An Empirical Investigation of Factors Affecting Student Satisfaction.” Journal of Education for Business, 85 (2), 95-100.

8. Berman, Jeffrey and Leah Ritchie (2006), "Competencies of Undergraduate Business Students." Journal of Education for Business, 81 (4), 205-209.

9. Bisoux, Tricia (2009), "Next Generation Education," BizEd, (May/June), 24-30.

10. Bisoux, Tricia (2010), "The Connected Capitalists," BizEd, (May/June), 24-33.

11. Butler, Deborah, Lisa Johnson, and Benjamin Forbes (2008), “An Examination of Skills-Based Leadership Coaching Courses in an MBA Program.” Journal of Education for Business, 83 (4), 227-232.

12. Callanan, Gerard A. and David F. Perri (2006), "Teaching Conflict Management Using a Scenario-Based Approach.” Journal of Education for Business, 81 (3), 131-139.

13. Cannon, David M., Helen A. Klein, Lori L. Koste, and Simha R. Magal (2004), "Curriculum Integration Using Enterprise Resource Planning: An Integrative Case Approach.” Journal of Education for Business, 80 (2), 93-101.

14. Cauley, Fattaneh G., K. Damon Aiken, and L. Keith Whitney (2009), “Technologies Across Our Curriculum: A Study of Technology Integration in the Classroom.” Journal of Education for Business, 85 (2), 114-118.

15. Chyung, Seung Y., Donald Stepich, and David Cox (2006), "Building a Competency-Based Curriculum Architecture to Educate $21^{\text {st }}$-Century Business Practitioners." Journal of Education for Business, 81 (6), 307-314. 
16. Close, Angeline G., Ashutosh Dixit, and Naresh K. Malhotra (2005), "Chalkboards to Cybercourses: The Internet and Marketing Education," Marketing Education Review, 15 (Summer), 81-94.

17. Conrad, Dan and Diane Hedin (1991), "School-Based Community Service: What We Know from Research and Theory," The Phi Delta Kappan, 72 (June), 743-749.

18. Cornelius, Nelarine, James Wallace, and Rana Tassabehji (2007), "An Analysis of Corporate Social Responsibility, Corporate Identity and Ethics Teaching in Business Schools," Journal of Business Ethics, 76, 117-135.

19. Crittenden, Victoria and Arch G. Woodside (2007), "Building Skills in Thinking: Toward a Pedagogy in Metathinking." Journal of Education for Business, 83 (1), 37-44.

20. Denton, James W., Virginia Franke, Kleist N. Surendra (2005), "Curriculum and Course Design: A New Approach Using Quality Function Deployment.” Journal of Education for Business, 81 (2), 111-117.

21. Dewey, John (1933), How We Think, Boston: Heath.

22. Dewey, John (1934), Art as Experience, New York: Minton Balch and Co.

23. Dewey, John (1938), Experience and Education, New York: Collier.

24. Dacko, Scott G. (2006), "Narrowing the Skills Gap for Marketers of the Future," Marketing Intelligence \& Planning, 24 (3), 283-295.

25. Dillon, Michael, Pat McCaskey, and Eric Blazer (2011), "MBA Internships: More Important than Ever." Journal of Education for Business, 86 (1), 44-49.

26. Dixon, Marlene A., George B. Cunningham, Michael Sagas, Brian A. Turner, and Aubrey Kent (2005), "Challenge is Key: An Investigation of Affective Organizational Commitment in Undergraduate Interns." Journal of Education for Business, 80 (3), 172-180.

27. Dynan, Linda, Tome Cate, and Kenneth Rhee (2008), "The Impact of Learning Structure on Students' Readiness for Self-Directed Learning.” Journal of Education for Business, 84 (2), 96-100.

28. Eastman, Jacqueline K., Rajesh Iyer, and Kevin L. Eastman (2011), "Business Students' Perceptions, Attitudes, and Satisfaction with Interactive Technology: An Exploratory Study." Journal of Education for Business, 86 (1), 36-43.

29. Fombrun, Charles J. (1996), Reputation: Realizing Value from the Corporate Image, Boston: Harvard Business School Press.

30. Ferrell, O. C. and Linda Ferrell (2008), “A Macromarketing Ethics Framework: Stakeholder Orientation and Distributive Justice," Journal of Macromarketing, 28 (1), 24-32.

31. Finney, Sherry and Joanne Pyke (2008), "Content Relevance in Case-Study Teaching: The Alumni Connection and Its Effect on Student Motivation." Journal of Education for Business, 83 (5), 251-258.

32. Frank, Gary, Emeka Ofobike, and Suzanne Gradisher (2009), "Teaching Business Ethics: A Quandary for Accounting Educators." Journal of Education for Business, 85 (3), 132-138.

33. Frye, Northrop (1963), The Educated Imagination, Bloomington, IN: Indiana University Press.

34. Fullan, Michael (2001a). Implementing Change at the Building Level. In W. Owings and L. Kaplan (Eds.), Critical and Emerging Issues in Educational Leadership. Thousand Oaks, CA: Corwin Press.

35. Fullan, Michael (2001b), "Leading in a Culture of Change, San Francisco, CA: Jossey-Bass

36. Fullan, Michael (2007), The New Meaning of Educational Change, New York: Teachers College Press.

37. Gardiner, Lorraine R., Gail Corbitt, and Steven J. Adams (2009), "Program Assessment: Getting to a Practical How-To Model." Journal of Education for Business, 85 (3), 139-144.

38. Gardner, Howard (1983), Frames of Mind: The Theory of Multiple Intelligences, New York: Basic.

39. Gardner, Howard (1999), Intelligence Reframed: Multiple intelligences for the 21 st century, New York: Basic.

40. Gerhardt, Megan (2007), "Teaching Self-Management: The Design and Implementation of SelfManagement Tutorials." Journal of Education for Business, 83 (1), 11-18.

41. Gibson, Shanan G., Michael L. Harris, and Susan M. Colaric (2008), "Technology Acceptance in an Academic Context: Faculty Acceptance of Online Education." Journal of Education for Business, 83 (6), 355-359.

42. Goel, Rajni and Ronald L. Straight (2005), "Using Real Datasets for Interdisciplinary Business/Economics Projects." Journal of Education for Business, 80 (5), 259-268.

43. Goorha, Prateek and Vijay Mohan (2009), "Understanding Learning Preferences in the Business School Curriculum.” Journal of Education for Business, 85 (3), 145-152. 
44. Govekar, Michele A. and Meenakshi Rishi (2007), "Service Learning: Bringing Real-World Education Into the B-School Classroom." Journal of Education for Business, 83 (1), 3-10.

45. Gremler, Dwayne D., K. Douglas Hoffman, Susan M. Keaveney, and Lauren K. Wright (2000), "Experiential Learning Exercises in Services Marketing Courses," Journal of Marketing Education, 22 (April), 35-44.

46. Grzeda, Maurice, Rana Haq, and Rolland LeBrasseur (2008), “Team Building in an Online Organizational Behavior Course.” Journal of Education for Business, 85 (5), 275-282.

47. Gundersen, David E., Ernest A. Capozzoli, and Rajasree K. Rajamma (2008), "Learned Ethical Behavior: An Academic Perspective." Journal of Education for Business, 83 (1), 315-324.

48. Hansen, Randall S. (2006), "Benefits and Problems with Student Teams: Suggestions for Improving Team Projects." Journal of Education for Business, 82 (1), 11-19.

49. Hazeldine, Mary and Morgan Miles (2007), "Measuring Entrepreneurship in Business Schools." Journal of Education for Business, 82 (4), 234-240.

50. Heinrichs, John H. and Jeen-Su Lim (2009), "Information Literacy and Office Tool Competencies: A Benchmark Study." Journal of Education for Business, 85 (3), 153-164.

51. Herzberg, Frederick, Bernard. Mausner, and Barbara B. Snyderman (1959), The Motivation to Work (2nd ed.), New York: John Wiley \& Sons.

52. Hilder, Monika B. (2005), "Teaching Literature as an Ethic of Care," Teaching Education, 16 (March), 41 50.

53. Holowczak, Richard D. (2005), "Incorporating Real-Time Financial Data into Business Curricula.” Journal of Education for Business, 81 (1), 3-8.

54. Hunt, Shelby and Debra Laverie (2004), "Experiential Learning and the Hunt-Vitell Theory of Ethics: Teaching Marketing Ethics by Integrating Theory and Practice," Marketing Education Review, 14 (Fall), 114.

55. Hyman, Michael R. and Jing Hu (2005), “Assessing Faculty Beliefs about the Importance of Various Marketing Job Skills.” Journal of Education for Business, 81 (2), 105-110.

56. Kerlinger, Fred N. and Howard B. Lee (2000), Foundations of Behavioral Research, Beverly, MA: Wadsworth.

57. Kolb, David A. (1984), Experiential Learning: Experience as the Source of Learning and Development. Englewood Cliffs, NJ: Prentice Hall.

58. Kolb, Alice Y. and Davidl A. Kolb (2005), Learning Styles and Learning Spaces: Enhancing Experiential Learning in Higher Education. Academy of Management Learning \& Education 4 (2), 193-212.

59. Kotter, John P., and Dan S. Cohen (2002), The Heart of Change: Real Life Stories of How People Change their Organizations. Boston: Harvard Business School Press.

60. Krentler, Kathleen A. and Laura A. Willis-Flurry (2005), "Does Technology Enhance Actual Student Learning? The Case of Online Discussion Boards." Journal of Education for Business, 80 (6), 316-321.

61. Lam, Monica (2009), "Effectiveness of Web-Based Courses on Technical Learning." Journal of Education for Business, 84 (6), 323-331.

62. Landry, Raymond, Glen D. Moyes, and Angelica C. Cortes (2004), "Ethical Perceptions Among Hispanic Students: Differences by Major and Gender.” Journal of Education for Business, 80 (2), 102-108.

63. Levenburg, Nancy M., Paul M. Lane, and Tomas V. Schwarz (2006), "Interdisciplinary Dimensions of Entrepreneurship.” Journal of Education for Business, 81 (5), 275-281.

64. Lillly, Brian and Michael J. Tippins (2002), "Enhancing Student Motivation in Marketing Classes: Using Student Management Groups,” Journal of Marketing Education, 24 (3), 253-264.

65. Littky, Dennis, and Samantha Grabelle (2004), The Big Picture: Education is Everyone's Business. Alexandria, VA: Association for Supervision and Curriculum Development.

66. Maher, Jill K. and Rene Shaw Hughner (2005), "Experiential Marketing Projects: Student Perceptions of Live Case and Simulation Methods," Journal for Advancement of Marketing Education, 7 (Winter), 1-10.

67. Markulis, Peter, Avan R. Jassawalla, and Hemant Sashittal (2006), "The Impact of Leadership Modes on Team Dynamics and Performance in Undergraduate Management Classes." Journal of Education for Business, 81 (3), 145-150.

68. Markus, George B., Jeffrey P. F. Howard, and David C. King (1993), "Integrating Community Service and Classroom Instruction Enhances Learning: Results from an Experiment," Educational Evaluation and Policy Analysis, 15 (Winter), 410-419. 
69. Mars, Matthew M. and Sharon Garrison (2009), "Socially-Oriented Ventures and Traditional Entrepreneurship Education Models: A Case Review." Journal of Education for Business, 84 (4), 290-296.

70. Marshall, Leisa Lynn (2007), "Measuring Assurance of Learning at the Degree Program and Academic Major Levels." Journal of Education for Business, 83 (2), 101-109.

71. Martell, Kathryn (2007), “Assessing Student Learning: Are Business Schools Making the Grade?” Journal of Education for Business, 82 (4), 189-195.

72. Martelli, Joseph and Patricia Abels (2010), "The Education of a Leader: Educational Credentials and Other Characteristics of Chief Executive Officers." Journal of Education for Business, 85 (4), 209-217.

73. McCarthy, Anne M. and Mary L. Tucker (1999). Student Attitudes Toward Service-Learning: Implications for Implementation. Journal of Management Education, 23 (5), 554-573.

74. McCarthy, Patricia R. and Henry M. McCarthy (2006), "When Case Studies Are Not Enough: Integrating Experiential Learning into Business Curricula." Journal of Education for Business, 81 (4), 201-204.

75. McEvily, Bill, Vincenzo Perrone, and Akbar Zaheer (2003), "Trust as an Organizing Principle," Organization Science, 14 (January-February), 91-103.

76. McRae-Campbell, Linda (1988), "Whole Person Education: Nurturing the Compassionate Genius in Each of Us," In Context, 18 (Winter), 16-18.

77. MacRae-Campbell, Linda (1997), Transforming Education. Langley, WA: Context Institute.

78. Miles, Morgan P., Mary F. Hazeldine, and Linda S. Munilla (2004), "The 2003 AACSB Accreditation Standards and Implications for Business Faculty: A Short Note.” Journal of Education for Business, 80 (1), 29-34.

79. Miller, Fred, W. Glynn Mangold, and Terry Holmes (2006), "Integrating Geographic Information Systems (GIS) Applications Into Business Courses Using Online Business Geographics Modules.” Journal of Education for Business, 82 (2), 74-79.

80. Mitry, Darryl J. (2008), "Using Cultural Diversity in Teaching Economics: Global Business Implications." Journal of Education for Business, 84 (2), 84-89.

81. Muncy, James A. (2006), "Implications of Contemporary Intelligence Theories to Marketing Education." Journal of Education for Business, 81 (6), 301-306.

82. Munoz, Caroline and Ann Huser (2008), "Experiential and Cooperative Learning: Using a Situation Analysis Project in Principles of Marketing." Journal of Education for Business, 83 (4), 214-220.

83. Murphy, Patrick E. (2005), "Sustainable Marketing," Business and Professional Ethics Journal, 24 (1 \& 2), 171-198.

84. National and Community Service Act (1990), Public Law 103-82, Statute 3127, S. 1430, $101^{\text {st }}$ Congress of the United States, $2^{\text {nd }}$ Session, November 16.

85. National and Community Service Trust Act (1993), Public Law 101-690, Statute 785, H.R. 2010, $103^{\text {rd }}$ Congress of the United States, $1^{\text {st }}$ Session, September 21.

86. Nguyen, Nhung T., M. Tom Basuray, William P. Smith, Donald Kooka, and Donald N. McCulloh (2008), "Ethics Perception: Does Teaching Make a Difference?" Journal of Education for Business, 84 (2), 66-75.

87. Nicholson, Carolyn Y. and Michelle DeMoss (2009), "Teaching Ethics and Social Responsibility: An Evaluation of Undergraduate Business Education at the Discipline Level." Journal of Education for Business, 84 (4), 213-218.

88. Page, Diana and Arup Mukherjee (2007), "Promoting Critical-Thinking Skills By Using Negotiation Exercises." Journal of Education for Business, 82 (5), 251-257.

89. Pamykalski, James J., Paul Dion, and James L. Brock (2008), “A Structural Equation Model for Predicting Business Student Performance.” Journal of Education for Business, 83 (3), 159-164.

90. Payne, Stephen L., Jan Flynn, and J. Michael Whitfield (2008), “Capstone Business Course Assessment: Exploring Student Readiness Perspectives.” Journal of Education for Business, 83 (3), 141-146.

91. Peach, Brian E., Arup Mukherjee, and Martin Hornyak (2007), “Assessing Critical Thinking: A College's Journey and Lessons Learned." Journal of Education for Business, 82 (6), 313-320.

92. Peng, Jacob C. (2009), "Using an Online Homework System to Submit Accounting Homework: Role of Cognitive Need, Computer Efficacy, and Perception." Journal of Education for Business, 84 (5), 263-268.

93. Peters, Michael H., Bryan R. Kethley, and Kimball Bullington (2005), "Course Design Using the House of Quality." Journal of Education for Business, 80 (6), 309-315.

94. Pfeffer, Jeffrey and Christina T. Fong (2004), "The Business School: Some Lessons from the U.S. Experience," Journal of Management Studies, 41, 1501-1520. 
95. Phillips, Susan (2004), Ethics Education in Business Schools, Report of the Ethics Education Task Force to AACSB International's Board of Directors, Tampa, FL, 1-23.

96. Plice, Robert K. and Bruce A. Reinig (2009), "Leveraging Alumni and Business Community Relations to Assess the Information Systems Curriculum." Journal of Education for Business, 84 (3), 142-150.

97. Porter, Michael E. and Mark R. Kramer (2006), "Strategy and Society: The Link between Competitive Advantage and Corporate Social Responsibility," Harvard Business Review, 84 (December), 3-16.

98. Pringle, Charles and Mitri Michel (2007), "Assessment Practices in AACSB-Accredited Business Schools.” Journal of Education for Business, 82 (4), 202-211.

99. Pritchard, Robert E., Michael S. Saccucci, and Gregory C. Potter (2010), Evaluating a Program Designed to Demonstrate Continuous Improvement in Teaching at an AACSB-Accredited College of Business at a Regional University: A Case Study." Journal of Education for Business, 85 (5), 280-283.

100. Quible, Zane K. (2005), “Blogs and Written Business Communication Courses: A Perfect Union.” Journal of Education for Business, 80 (6), 327-332.

101. Rendtorff, Jacob D. (2009), Responsibility, Ethics and Legitimacy of Corporations, Copenhagen, Denmark: Copenhagen Business School Press.

102. Robinson, Chin C. and Hallet Hullinger (2008), "New Benchmarks in Higher Education: Student Engagement in Online Learning.” Journal of Education for Business, 84 (2), 101-109.

103. Rogers, Carl R. and H. Jerome Freiberg (1993), Freedom to Learn, 3rd edition, New York: Merrill.

104. Rothman, Miriam (2007), "Lessons Learned: Advice to Employers From Interns.” Journal of Education for Business, 82 (3), 140-144.

105. Ryan, Richard M. and Edward L. Deci (2000), "Intrinsic and Extrinsic Motivations: Classic Definitions and New Directions," Contemporary Educational Psychology, 25, 54-67.

106. Sautter, Pookie (2007), "Designing Discussion Activities to Achieve Desired Learning Outcomes: Choices Using Mode of Delivery and Structure,” Journal of Marketing Education, 29 (2), 122-131.

107. Sautter, Pookie, Eric R. Pratt, and Kevin J. Shanahan (2000), "The Marketing WebQuest: An Internet Based Experiential Learning Tool.” Marketing Education Review, 10 (Spring), 47-55.

108. Schlee, Regina P., Marry T. Curren, and Katrin R. Harich (2009), "Building a Marketing Curriculum to Support Courses in Social Entrepreneurship and Social Venture Competitions.” Journal of Marketing Education, 31 (1), 5-15.

109. Schloemer, Paul and Kathleen Brenan (2006), "From Students to Learners: Developing Self-Regulated Learning." Journal of Education for Business, 82 (2), 81-87.

110. Schneider, Kenneth C. (1983), "Teaching Ethics in Marketing Research: An Experiential Approach,” Journal of Marketing Education, 5 (12), 27-34.

111. Sciglimpaglia, Donald and Howard R. Toole (2009), "Use of Student Field-Based Consulting in Business Education: A Comparison of American and Australian Business Schools." Journal of Education for Business, 85 (2), 68-77.

112. Shinnar, Rachel, Mark Pruett, and Bryan Toney (2009), "Entrepreneurship Education: Attitudes Across Campus." Journal of Education for Business, 84 (3), 151-159.

113. Smith, David E. and Darryl J. Mitry (2008), "Investigation of Higher Education: The Real Costs and Quality of Online Programs.” Journal of Education for Business, 83 (3), 147-152.

114. Smolira, Joseph C. (2008), "Student Perceptions of Online Homework in Introductory Finance Courses.' Journal of Education for Business, 84 (2), 90-95.

115. Stivers, Bonnie and Jeffrey Phillips (2009), "Assessment of Student Learning: A Fast-Track Experience." Journal of Education for Business, 84 (5), 258-262.

116. Sulaiman, Ainin and Suhana Mohezar (2006), "Student Success Factors: Identifying Key Predictors." Journal of Education for Business, 81 (6), 328-333.

117. Taylor, Edward W. (2007), “An Update of Transformative Learning Theory: A Critical Review of the Empirical Research (1999-2005),” International Journal of Lifelong Education, 26 (March-April), 173191.

118. Theroux, James M. (2009), "Real-Time Case Method: Analysis of a Second Implementation.” Journal of Education for Business, 84 (6), 367-373

119. Tschannen-Moran, Megan (2004), Trust Matters: Leadership for Successful Schools, San Francisco: Jossey-Bass. 
120. Volkema, Roger and Cheryl Rivers (2008), "Negotiating on the Internet: Insights From a Cross-Cultural Exercise.” Journal of Education for Business, 83 (3), 165-172.

121. Weible, Rick (2009), “Are Universities Reaping the Available Benefits Internship Programs Offer?” Journal of Education for Business, 85 (2), 59-63.

122. Weinstein, Art and Hilton Barrett (2007), "Value Creation in the Business Curriculum: A Tale of Two Courses." Journal of Education for Business, 82 (6), 339-336.

123. Weldy, Teresa G. and David L. Turnipseed (2010), "Assessing and Improving Learning in Business Schools: Direct and Indirect Measures of Learning." Journal of Education for Business, 85 (5), 268-273.

124. White, Charles S. (2007), "Levels of Understanding - A Guide to the Teaching and Assessment of Knowledge." Journal of Education for Business, 82 (3), 159-163.

125. Wilson, Barbara A. (2008), "Predicting Intended Unethical Behavior of Business Students." Journal of Education for Business, 83 (4), 187-195.

126. Wingfield, Sue S. and Gregory S. Black (2005), “Active Versus Passive Course Designs: The Impact on Student Outcomes." Journal of Education for Business, 81 (2), 119-123.

127. Winter, Janet K., Karen K. Waner, and Joan C. Neal-Mansfield (2008), "Team Climate and Productivity for Similar Majors Versus Mixed Majors.” Journal of Education for Business, 83 (5), 265-269.

128. Wong, David (2007), "Beyond Control and Rationality: Dewey, Aesthetics, Motivation, and Educative Experiences, Teachers College Record, 109 (1), 192-220.

129. Xu, Yang and Yi Tang (2010), "Student Learning in Business Simulation: An Empirical Investigation." Journal of Education for Business, 85 (4), 223-228.

130. Young, Mark R. (2005), "The Motivational Effects of the Classroom Environment in Facilitating SelfRegulated Learning," Journal of Marketing Education, 27 (1), 25-40. 
NOTES 